\title{
Til minne om Nils Christie
}

\author{
Kjersti Ericsson
}

Nils Christie døde 27. mai 2015, 87 år gammel. Hvor skal en begynne i forsøket på å gi et bilde av hans virke? Kanskje med det engasjerte samfunnsmennesket. 10. mai 2015 hadde han sin siste artikkel på trykk i en norsk avis. Det var et innlegg i debatten om hvordan regjeringskvartalet i Oslo bør utformes. Dagen etter at han døde, skulle han egentlig vært på møte med kunnskapsminister Torbjørn Røe Isaksen, for å forklare ham at skoler først og fremst trenger å være gode på én ting: å like elever.

Nils hadde stor respekt for forskningens egenart. Forskning skal være drevet av nysgjerrighet, den skal ikke styres, og den skal være kritisk. Men forskning som ikke er i dialog med samfunnet rundt seg, var fremmed for ham. Det preget måten han uttrykte seg på. «Ord og tegn kan skape broer. Vakre og nyttige broer. Men de kan også skape sperrer, som ved muntlige ord til døve eller ved de høyt spesialiserte ord brukt utenom spesialistenes krets (...) Den store samtalen må bevares. Det gjør vi best ved å bygge ned skiller mellom folk og ved å bevare respekten for dagliglivets små ord,» skriver han i forordet til den siste boka si, Små ord for store spørsmål som kom i 2009. Og han levde som han lærte.

Dialogen hans med samfunnet var både nasjonal og global. Hjemme deltok han i stiftelsen av foreningen for kriminalreform, KROM, i 1970. I seg sjøl var han også en verdensomspennende bevegelse for human kriminalpolitikk og mindre bruk av fengsel. Han besøkte alle deler av kloden for å overbevise fengselsledere, administratorer og myndighetspersoner, og for å oppmuntre og inspirere allierte. Få, om noen, kjente innsida av verdens fengsler så godt som Nils Christie. I bøkene Pinens begrensning og Kriminalitetskontroll som industri er de faglige argumentene nedfelt. De ble, i likhet med flere andre av de 15 bøkene hans, flittig oversatt. Nils Christie kan leses på 20 forskjellige språk.

I Norge fikk vi konfliktrådene, inspirert av Nils' tanker om alternativer til den rettslige måten å møte konflikter på. Nils sto utvilsomt for farskapet, sjøl om han nok ikke allid var like fornøyd med sitt avkom. Men farskjærligheten bevarte han. Og artikkelen «Conflict as property» ble en slags programartikkel for den globale strømningen som går under navnet «restorative justice».

Narkotikapolitikken er et tredje område der Nils ønsket å bevege samfunnet, både sitt eget og verdenssamfunnet, der «krigen mot narkotika» ga seg stadig mer 
groteske utslag. Boka Den gode fiende, som han skrev sammen med Kettil Bruun, fikk stor betydning. Stor betydning fikk også Nils personlig for en rekke stoffavhengige enkeltmennesker, som han prøvde å gjøre hverdagen litt enklere for. Nils var ikke den typen som brenner for å forandre samfunnet, men helst ikke vil bli forstyrret av enkeltmennesker. Mange som er blitt nedvurdert, oversett og har fătt noen harde slag av livet fant en sann venn og støttespiller i Nils. Det var aldri noe abstrakt ved samfunnsengasjementet hans. Kanskje var det også derfor han kunne gi sine faglige innsikter en så levende og inkluderende form.

Det var Johs Andenæs som fikk den usedvanlig gode ideen å rekruttere den unge Nils Christie til det nyopprettete Institutt for kriminologi og strafferett i 1954. Da hadde Andenæs allerede fått ham til å skrive magistergradsavhandling om norske fangevoktere i konsentrasjonsleirer for jugoslaviske krigsfanger under andre verdenskrig. Den forskeren vi møter i magistergradsavhandlingen fra 1952 er så utvilsomt den samme Nils Christie som verden seinere lærte å kjenne. Boka kom da også med som ett av Norges 25 viktigste sosiologiske verker i en kanonkåring i 2009.

I 1959 ble han Dr. philos, og samme år dosent i kriminologi. I 1966 ble han Norges første professor i kriminologi.

Det tok ikke lang tid før han også markerte seg på nordisk plan. Nordisk samarbeidsråd for kriminologi ble startet i 1962, etter en utredning med Andenæs som leder og Nils som sekretær. Helt fra starten av var han med på å prege rådets utvikling, der han sto for det standpunktet at vekt på det nordiske og komparative ikke måtte gjennomføres på en måte som gjorde vold på nasjonale særegenheter og profil. I perioden 1979-1982 ledet han rådet. For de fleste av oss er forskerseminarene samarbeidsrådets livsnerve, og mange har sterke minner om Nils' faglige og sosiale nærvær. Herværende tidsskrift har også nytt godt av innsatsen hans, både som artikkelforfatter og som redaksjonsmedlem fra 1970 til 1998.

Nils var en strålende foreleser, med samme ivrige formidlingsvilje, uansett hvilket publikum han snakket til, leg eller lærd, internasjonale notabiliteter eller beboere på Vidaråsen landsby for mennesker med psykisk utviklingshemming. Publikum er kanskje et ord han ikke ville likt i denne sammenhengen, med sin tro på at ingen bør være bare tilhører - alle har det i seg å bidra til den store samtalen. Han prøvde å forvandle enhver sosial sammenheng til et seminar, fra lunsjpausene på instituttet til aksjonen mot kraftutbygging i Alta-Kautokeinovassdraget i Finnmark, der han fikk en hutrende gjeng fastlenkede demonstranter til å diskutere og reflektere over konfliktløsning, sivil ulydighet, forholdet mellom minoritet og majoritet. 
Nils hadde stor anseelse og innflytelse langt utover eget fagmiljø og landets grenser. Han var mange ganger prisbelønt og hadde tre æresdoktorater. Denne innflytelsen oppnådde han, ikke ved å tenke i takt med de strømningene som representerte makt og prestisje, men ved å løfte fram en annen slags fornuft. Hvis jeg ikke husker feil, formulerte han denne fornuften omtrent slik ved et eller annet jubileum: Mitt hovedanliggende har vært å styrke det sivile samfunn. Nils hadde en grunnleggende tro på vanlige menneskers visdom og oppfinnsomhet. Faglig har han i utallige varianter begrunnet hvorfor vi må organisere samfunnet slik at denne visdommen og oppfinnsomheten får mulighet til å komme til uttrykk. Et beslektet hovedtema i Nils' produksjon, fra magistergradsavhandlingen og til de siste arbeidene hans, er nærhet og avstand: $\AA$ advare mot det fryktelige som kan ligge $\mathrm{i}$ kim når den sosiale avstanden mellom mennesker vokser, var maktpåliggende for ham.

Nils er død. Men mye vil fortsette å leve etter ham.

Oslo 2/6-2015 